\title{
Does Popular Management Literature Lead Managers Up the Linguistic Garden Path? A Comparison of Popular Prescriptive 'How-to' Manage- ment Texts and a Descriptive Analysis of Workplace Interaction
}

\begin{abstract}
Popular management literature promotes the idea that certain management styles have a reflexive relationship with certain ways of talking. Consequently, by using prescribed ways of talking, certain management styles will be achieved and that, reflexively, certain management styles favor certain ways of talking. Using conversation analysis (CA) as a research methodology, this paper compares the prescriptive language advice of popular management literature as regards facilitation with video-taped data of naturally-occurring talk in a business meeting. Findings indicate that the intuitive insights on language use offered by popular management literature ignore the indexical nature of language use whereby the 'meaning' of any utterance and what that utterance does depends on its context of use. In short, such popular literature may lead managers up the (linguistic) garden path and may in fact be of little help in practice. The paper ends with a call for language advice in such literature to be more descriptive and less prescriptive.
\end{abstract}

\section{Introduction}

Popular management literature is inundated with books and articles on how to be a successful manager by improving one's communication skills. Such literature often sets out communicative recipes for being a good manager in the genre of 10 tips for successfully managing meetings etcetera. Some of these texts go further by giving lists of expressions to use and some provide imaginary dialogues that purport to show such communicative strategies in action. For example to be a facilitator, prescriptive texts might imply that by using expressions such as thank you for sharing, could you say more about that, or what do others think might be enough to ensure that one's interactions are per se facilitative. Using conversation analysis (CA) as a research methodology and taking the case of popular management literature on facilitation, this paper examines the in situ use of so-called facilitative language and compares its actual use in naturally-occurring workplace interaction with the claims of popular management texts on facilitation. Findings indicate that the linguistic prescriptions offered in popular 'how-to' literature on facilitation, in fact, do not necessarily correspond to the analysis of what these expressions 'do' in naturally-occurring talk. Consequently, the value of such prescriptions is called into question.

This paper is divided into four sections. First notions of facilitation are discussed and examples are given of how it is popularly believed that the management discourse of facilitation can be synthesized into glossaries of facilitative language. Second, CA as a research methodology is introduced. Third, a transcript of a management meeting is analyzed. Finally, observations and conclusions are offered.

\footnotetext{
* Jonathan Clifton

University of Lille 3

Faculty of Applied Linguistics

14 Place Bodart Timal

BP 447

59058

France

jonathan.clifton@univ-lille3.fr
} 


\title{
2. Facilitation
}

As a working definition of facilitation, the following definition taken from $\mathrm{BNET}^{1}$, a management website, which describes itself as providing action-oriented intelligence for managerial professionals, is offered:

\begin{abstract}
[facilitation is] the process of helping groups, or individuals, to learn, find a solution, or reach a consensus, without imposing or dictating an outcome. Facilitation works to empower individuals or groups to learn for themselves or find their own answers to problems without control or manipulation. Facilitators need good communication skills, including listening, questioning, and reflecting. Facilitation is used in a variety of contexts including training, experiential learning, conflict resolution, and negotiation.
\end{abstract}

Moreover, as stated in the introduction, many popular management books and websites then go on to give expressions that could be typically used to achieve the management style which they are promoting. For example, the following text, taken from a management consultancy website ${ }^{2}$, defines facilitation in terms of expectable interactional patterns and then goes on to give examples of facilitator talk:

\begin{abstract}
The most important speaking of the facilitator involves what's said while interacting with the group to promote discussion, to draw out and motivate others, to move the processes forward, and to promote trust. In these intentions and others, the facilitator uses questions and probing to a great extent. Questioning is a powerful facilitation tool, and can be used to draw forth participation and creative involvement. Open-ended questions that do not imply an answer are best used in facilitation, as they allow the group to respond freely. Open-ended questions are those that allow free response, such as:
\end{abstract}

\begin{abstract}
Soliciting input: "What do you think? What would you add to this? How else could this be done? What more could follow?"
\end{abstract}

\begin{abstract}
Requesting advice: "What do you think we might do here? What options might we consider? How has anyone else done this before? What do you think might work here?"

Probing others for response: "Jeff, what do you think? Laurie, would you be willing to add to this?"
\end{abstract}

This approach to management-talk sometimes gives rise to glossaries of (decontextualised) expressions that can be used to 'do' facilitation and so, implicitly, the idea that there is a one-to-one correspondence between the utterance and the action that it performs is promoted. Moreover, such glossaries also tacitly suggest that the use of such expressions is enough in itself to ensure that a practitioner's interaction is facilitative (see appendix one for an example of such expressions). The problem with this is that such intuitive lists of expressions may be facilitative but this ignores the indexical nature of language whereby the meanings of words and the actions which they perform are dependent on the context in which they are used. For example, according to the context and the identities of the participants, the expression 'how are you' could 'do' a greeting or it could 'do' a request for medical information. Thus, in short, any expression in a glossary of facilitator talk may well do facilitation but, equally, it could be used to do other actions. So, from this perspective, implying a one-to-one relationship between expressions and actions is linguistically naïve and may be leading practitioners up the garden path.

Moreover, some popular management literature on facilitation goes further by providing invented dialogues of facilitative interaction. For example, the following invented dialogue, taken from a 'how-to' management book entitled Coaching People (McManus 2006), is used to illustrate how the use of open questions is facilitative because they allow the manager to uncover the employee's perspective, listen actively to what is said, and check for understanding (McManus 2006: 23).

1 BNET Business Dictionary. Available at: http://dictionary.bnet.com/definition/Facilitation.html

2 http://redesignresearch.com/about.htm 
1. Ilka: Gonzalo, how do you feel the project is going?

2. Gonzalo: Pretty well. We're on schedule.

3. Ilka ((nods her head))

4. Gonzalo: But it's tight. There's no room to spare.

5. Ilka: Because?

6. Gonzalo: Because when Jenna left, no one was hired to replace her.

7. Ilka: And because you've lost one person?

8. Gonzalo: It's going to be really hard to meet the deadline.

9. Ilka: Are you saying that you'll deliver on time, but it will be difficult? Or that you may not

10. be able to meet the deadline?

11. Gonzalo: Well, I think we can make the deadline, but there is a chance we might miss it.

12. Ilka: And if we want to be sure to finish on time?

13. Gonzalo: We'd need more help.

14. Ilka: Perhaps we could look into getting some temporary help.

In line one, Ilka asks a question which requires a conditionally relevant response which is provided in line 2 . This is received by a nod of the head which is understood as a continuer since Gonzalo continues his turn with an increment (i.e. a continuation to what could be grammatical and pragmatically complete turn). The facilitator, by probing further, is thus able to elicit more information. In the next turn, 'because' is spoken with rising intonation and is recognized by the employee as a question which again invites an increment which is provided in the following turn. In short, through the action of the facilitator, one extended turn at talk, giving the employee's full perspective, has been elicited (i.e. we're on schedule, but it's tight. There's no room to spare, because when Jenna left, no one was hired to replace her.). The facilitator then seeks the upshot to this, and again elicits the employee's perspective. In line 10, the facilitator asks a further clarifying question which leads to a respecification of the upshot and, by adding an increment onto this turn, the facilitator probes for a more extensive upshot which is received in line 13. The decision (a projection of future action) comes in the final line where the facilitator, now in possession of all the relevant information, announces the decision, "perhaps we could look into getting some temporary help". The dialogue therefore consists of a series of question and answer adjacency pairs that neatly illustrate the eliciting of a full response from an employee by a facilitator. Once the full response and its upshot have been elicited, the facilitator can decide upon action.

In short, the dialogue does little more than illustrate exactly what the writer intended it to do (i.e. open questions invite participation, idea-sharing, the exploration of alternatives, the uncovering attitudes and needs, and the establishment of priorities). This is hardly surprising since in order to illustrate the point a writer, even with the best intentions and having experience in the field, can image what he/she likes sitting in front of a computer. Such an approach to providing language advice can be seen to be a case of the tail wagging the head of the dog, whereby theorizing is dictating the 'data'. As a result, language advice is generated only by what is imaginable, reasonable and, de facto, unsurprising. Yet what is reasonable, imaginable, and unsurprising may not be the real situation. For example, Williams (1988) and Nelson (2000) have both drawn attention to the gulf between the prescribed language in textbooks and the language used in authentic business interaction. This, therefore, constitutes a strong argument for the use of naturally-occurring talk as the starting place for any analysis of 'what is going on' and for the provision of datadriven, and thus credible, advice to practitioners. 


\section{Methodology}

Whilst it is beyond the scope of this paper to provide a substantive review of CA as a research methodology (see, for example, Hutchby and Wooffitt, 2008), it suffices to say that conversation analysis is a fine-grained sequential analysis of talk-in-interaction based upon the analysis of transcripts of naturally-occurring talk. Through the process of transcription and analysis, the actions that are performed by talk, and the machinery by which these actions are achieved, is revealed. Despite the fact that CA has traditionally worked from a stance of indifference inherited from its ethnomethodological roots, CA is increasingly being used in an applied sense "to support efforts to make social life 'better' in some way, to provide data-based analytical suggestions for, or critiques of, the ways in which social life can be organized" (ten Have, 1999: 162). This has given rise to articles that use CA to give a critical edge to, for example, management studies (Clifton, 2006), medical interaction (Tapsall, 2000), and teaching/textbook design (Wong, 2002). CA is suited to this applied use for three reasons. First, the findings are empirically rather than theoretically (and thus possibly ideologically) grounded. This is because researchers approach transcription and analysis in a spirit of unmotivated looking (Sacks 1984: 27) so that observation becomes the basis for theorizing rather than vice-versa. As Sacks (1984: 25) points out, in this way, what is at first unimaginable can become visible to the observer whereas if one starts with a hypothesis, research is often constrained by what the research community can accept as reasonable. Second, since the recordings of naturally-occurring talk catch social life in flight, they represent events that actually happened and do not stand proxy for what a writer feels should happen or recollects has happened. Third, by examining what utterances mean in terms of how the participants orient to them as revealed in a second turn (Sacks et al. 1974: 728), CA provides an emic analysis of events that takes due account of the indexical nature of language.

\section{The data}

\subsection{Corpus of texts on facilitation}

Bearing in mind that this paper concentrates on popular management literature and, more specifically, the "how-to" style of literature that provides advice to would be facilitators, a Google search for sites on facilitation in management was performed and a corpus based on the first 20 sites that came up in this search was collected. The corpus was supplement by six books on facilitation which were available in the local library. Of these texts, ten gave expressions to use and three provided examples of imagined dialogues to exemplify facilitation-in-action. 16 sources gave no examples of expressions to use in order to achieve facilitation nor did they give imagined dialogues. In short, about $40 \%$ of the texts in the corpus can be said to promote a recipe book style of management: follow these linguistic prescriptions and you'll become the manager you desire. Such texts, therefore, implicitly promote the notion that there is a one-to-one correspondence between linguistic style and management style. None of the texts surveyed provided data based on direct observation of talk-in-interaction.

\subsection{The meeting}

The data for the analysis of naturally-occurring talk comes from a management meeting at a large language school in the north of France in which I used to work. The school, one of the main players in the highly competitive market of language training in the region, is dependent on the local chamber of commerce and industry but to a large extent it is self-financing. I was allowed to record a series of meetings in which the management team discussed issues such as the training of the language instructors, the company's portfolio of courses, quality issues relating to the teaching and so on. The meetings are attended by three senior teachers (given the pseudonyms Nigel, Liz, and Beth) and the director of the centre who chairs the meetings (given the pseudonym Alice). The meetings were held in French which was the official language of the company. They have been transcribed with an interlinear translation which aims to strike the balance between the pro- 
vision of a direct word for word translation and the provision of a readable text (see appendix two for a list of transcription symbols used). Despite the fact that three of the participants (Liz, Beth, Nigel) were not native speakers of French, this caused no apparent problem during the meetings since: they had all been in France for between 10 and 20 years; were all married to French native speakers and spoke French at home; all had higher degrees in French and in two cases they had been teachers of French in their native countries before coming to France.

Initially, following the CA tradition of basing any analyses strictly on intra-textual data derived from the transcripts, I had no intention of using the participants' comments to guide my research but, as Labov (1972: 88) points out, researchers can obtain relevant information when they have packed away their recording equipment and are on their way out of the research site. In this case, since I knew the participants well, without soliciting information, I was privy to their comments concerning what was happening during the meetings and I was faced with the dilemma of either ignoring such data and pretending it didn't exist or attempting to use it to shed light on my analysis (see Blommaert 1997 for an interesting discussion on this issue). Whilst not going as far as Moerman (1988) and arguing for a complete synthesis of CA and ethnography, Pomerantz (2005) and Pomerantz et al. (1997) justify the use of taking into account the participant's perspective on the grounds that, amongst other things, such comments can suggest areas that can be profitably analyzed by the researcher (Pomerantz 2005: 102). Though, they do justify the use of extra-textual data to guide the researcher, they are also quick to point out that taking into account the participant's perspective is not a substitute for, but is a complement to, rigorous intra-textual analysis. Therefore, working from this basis, I allowed comments from the participants to guide my 'looking' at the transcripts and the development of the research question. More specifically, whilst talking to Alice, she remarked that she tried to let everybody express themselves and then she would try to bring the ideas together. She, thus, portrayed herself as a facilitative manager. Yet, the other participants regarded her as a 'control freak.' This apparent divergence of perceptions of what was happening in the meetings guided, to some extent, my research concerns.

\section{The analysis}

The sequence of talk analyzed is a decision-making episode taken from one of the pedagogic meetings. Alice (the chair) initiates the episode by eliciting topic. Liz brings up the topic of the possibility of subscribing to a magazine (Time) and using it as a teaching resource. Alice immediately frames the idea as a problem. In the end, consensus is achieved to the effect that it is not a good idea to subscribe to Time and a decision is made not to subscribe. Significantly, during the course of the interaction, Liz reverses her opinion and goes with the emerging group consensus not to subscribe to Time.

\subsection{Topic initial elicitor - anything else}

In the following extract, Alice uses the topic initial elicitor (anything else) which introduces the topic of subscribing to a magazine. 


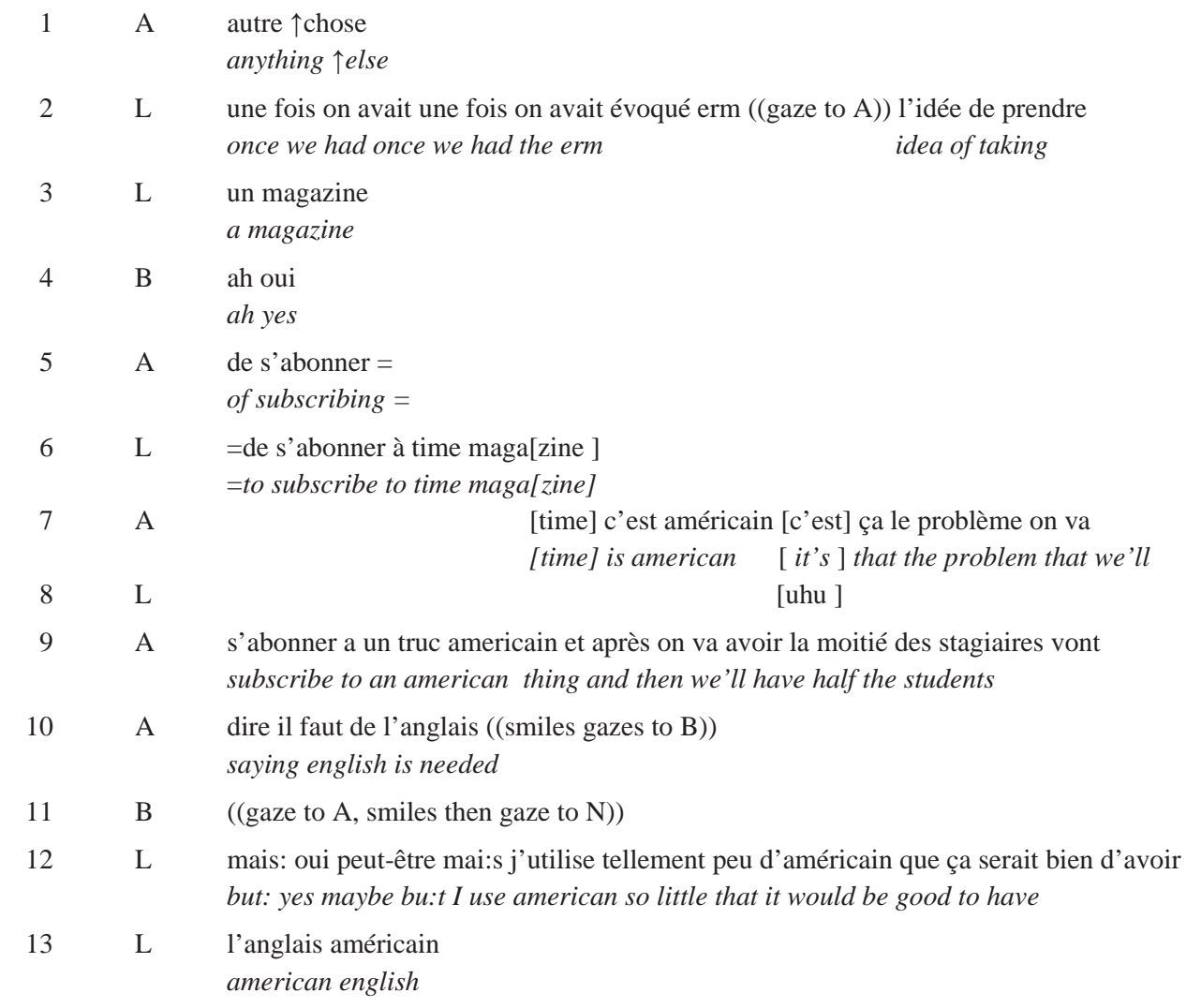

In line 1, Alice closes down the previous topic talk and initiates the next topic through use of the topic initial elicitor 'anything else', which is used to signal continued availability for talk but does not proffer a particular topic and if no topic is forthcoming then closing can be carried out (Button and Casey 1984). As is seen in appendix one, anything else, taken in isolation, can be seen as a 'facilitative expression' that invites participation. Further, many of the prescriptive texts about facilitation consider open questions to be per se facilitative because they encourage participation and so 'do' empowerment. However, as previously noted, the meaning of an utterance depends not on some decontextualized and prescribed list of words that are intuitively assumed to 'do' certain management styles but on its sequential position in the interaction. In this case, the utterance does solicit a next topic, but there is nothing that is necessarily facilitative in this (unless one assumes that anytime the floor is offered to another participant, this is necessarily empowering!).

In the talk following the topic initial elicitor, Alice (in line 7) immediately assesses this statement before Liz has an opportunity to develop her ideas. By placing an assessment in a sequentially first position, Alice is claiming epistemic primacy and displaying that she has superior knowledge and a better right to display knowledge than Liz. This is because by going second one could be seen to be following the lead of the previous turn and so going with the flow rather than having superior rights to have and display knowledge (Heritage \& Raymond 2005, Raymond \& Heritage 2006). Thus, in this sequence, rather than doing facilitation, 'anything else' simply mediates turns and in subsequent talk, we see a rapid claim that Alice's voice counts more than Liz's who has initiated the topic. Having made her (negative) assessment, a second assessment becomes sequentially relevant in the next turn (Pomerantz 1984). In this case (line 12: but: yes maybe but: I use american so little that it would be good to have american English), Liz carries out a dispreferred second assessment which comprises of weak agreement followed by disagreement (Pomerantz 1984). She thus publically and accountably disaligns with Alice's assessment and the scene is set for a resolution of this disagreement. 
In sum, there is nothing facilitative about Alice's use of an open question. Anything else serves as a topic initial elicitor and is used to mediate turns and introduce new topics. When Liz does introduce a topic, Alice assumes the right to assess it and so claims epistemic primacy: her opinion counts more than Liz's. She thus jockeys for a position that displays epistemic superiority vis-àvis Liz and which is hardly empowering or conducive to inviting participation.

\subsection{Word search}

In the following extract, which is a continuation of extract 1 , Beth, through helping Liz with a word search, carries out a facilitative action because it helps Liz to expand on her ideas and so to participate more fully in the talk.

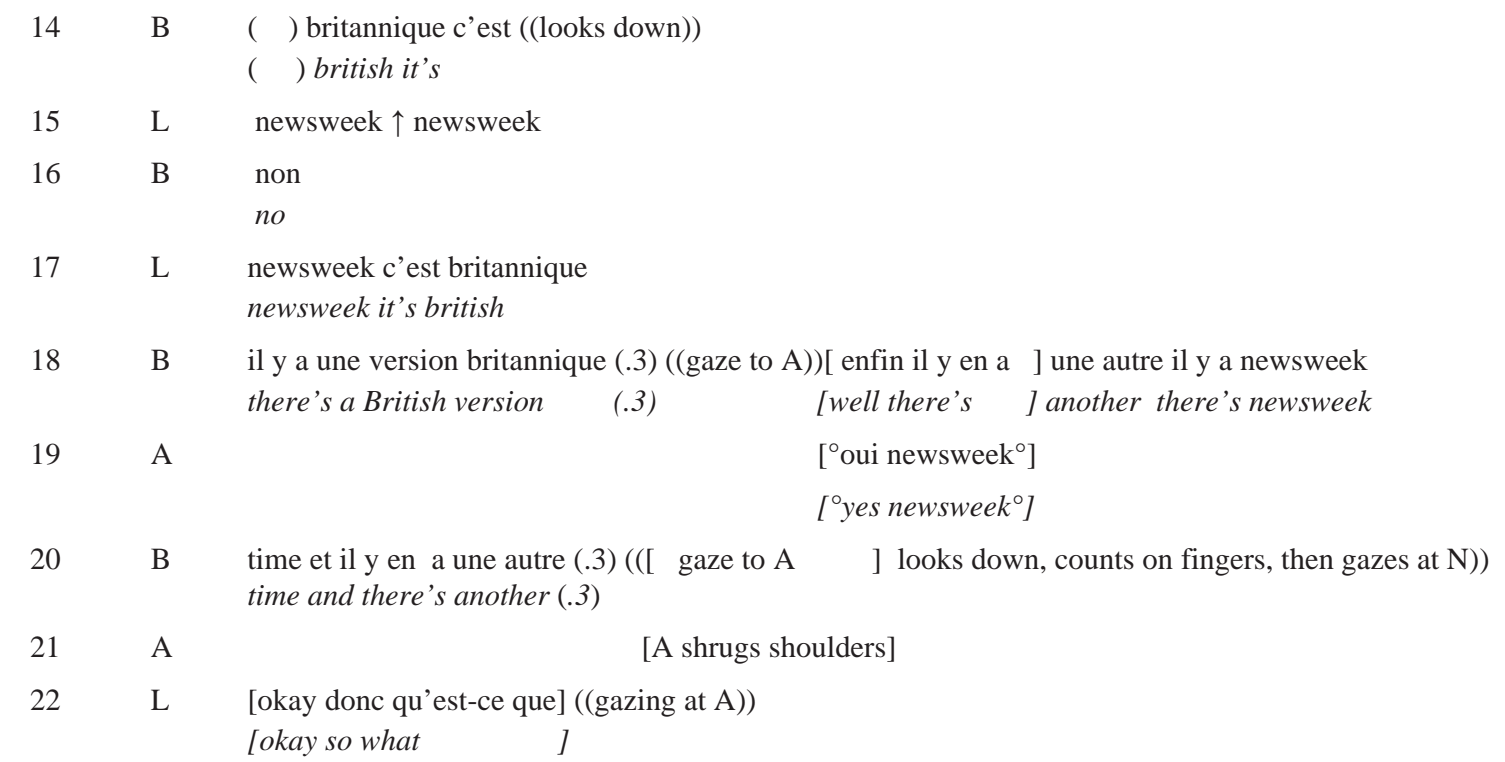

In line 14, Beth self-selects to initiate a search for a British magazine (british it's). By helping find a suitable British magazine, Beth is therefore helping Liz develop her suggestion and so can be seen to be doing facilitation. In line 15, Liz provides a candidate solution (Newsweek) and therefore responds positively to Beth's help in the word search. However, Beth rejects this and continues her search for another magazine. In line 18, she gazes at Alice and so invites her to help in the search and in line 20, she looks up, gazes at Nigel and so also invites him to participate in the search. By her eye gaze she tries to bring other team members into the word search to help Liz develop her idea. Thus, up to this point, Beth facilitates and enhances Liz's participation in the talk. Help with a word search though, whilst clearly facilitative, does not figure in the examples drawn from the corpus. It is as if Sacks' warning that a priori ideas will only reveal what is imaginable to the researcher (or in this case popular management writer) and that fine-grained analyzes of naturally-occurring data are required to reveal the seen but unnoticed machinery of talk and the actions that it performs.

\subsection{Irony}

In the continuation of the extract, Beth invites Nigel into the word search via her gaze (line: 23). However, Nigel treats the word search ironically and does identity work that seeks to distance Liz from participating in the talk. In short, on a negative note, one could add to the popular management prescriptions the obvious 'don't do irony' if one wants to encourage participation, yet none of the texts in the corpus specifically address this issue. 


\begin{tabular}{|c|c|c|}
\hline 23 & B & $\begin{array}{l}\text { [ il y avait un autre } \\
\text { [ there was another }\end{array}$ \\
\hline 24 & $\mathrm{~N}$ & £horse and $\uparrow$ hounds£ town and $\uparrow$ country ((gazing at B)) \\
\hline 25 & A & £town and country£ ((smiles gazing at $N))$ \\
\hline 26 & $\mathrm{~N}$ & home and garden ${ }^{\circ}$ home and garden ${ }^{\circ}$.hh he ((gazing at B $\left.)\right)$ \\
\hline 27 & B & $\begin{array}{l}\text { ((gaze at Nigel)) bon ((smiles, waves right arm in downward motion, palm out)) } \\
\text { good }\end{array}$ \\
\hline 28 & $\mathrm{~N}$ & {$\left[\right.$ eheheeh $\left.^{\circ} \cdot \mathrm{hh} \mathrm{heh}^{\circ}\right]$} \\
\hline 29 & $\mathrm{~L}$ & $\begin{array}{l}\text { [moi je suis d'avis ] qu'on qu'on s'abonne }((\text { gaze to } \mathrm{A})) \\
\text { [me my opinion is] that we that we subscribe }\end{array}$ \\
\hline
\end{tabular}

In line 24, Nigel fills the slot which has been attributed to him by Beth. But, despite fulfilling the sequential requirement of taking a turn that has been attributed to him, by supplying the names of a couple of magazines ${ }^{3}$ that are blatantly inappropriate for use in the classroom, the action performed by the turn is not conditionally relevant to the request for help in a word search. Such a sequential disjunction between what is projected as a conditionally relevant second pair part and the activity accomplished by the second pair part is a major feature of irony (Clift 1999). Moreover, as Clift (1999: 542) points out, "it is, then, the apparent mismatch of item and slot that serves consistently to perform one activity: evaluation." Nigel's turn is, therefore, hearable as a negative assessment of the search for an English magazine. Moreover, Nigel produces his turn with a smile voice which consists of "a markedly higher pitch and an intonational contour comparable to laughing during speaking but without any laughter tokens" (Buttny 2001: 317) and which displays an orientation to the word search as a laughable matter. The smile voice (see Jefferson 1979) invites affiliation as a next action and in this case receives it from Alice who repeats "£town and countryf" in a smile voice. Nigel then adds 'home and garden' to this list and then starts to laugh openly and, by repeating the joke, he displays appreciation of his own joke and does laughing at Liz. As Nigel laughs, he gazes at Beth thus eliciting a response from her. Beth responds to the laughter by, at first, disaligning by covering her face with her left hand, then she lets slip her left hand to cover her mouth and when she removes her hand it reveals a smile which signals appreciation as she orients her gaze to Nigel. As she says 'good', she waves her right arm, palm out, quickly downward which is hearable as signaling topic closure.

In line 29, Liz self-selects to terminate the relevance of the laughter at her. She does this by simultaneously taking up the topical import of the previous talk by suggesting that they subscribe to Time ("me my opinion is that we that we subscribe") and she closes down the laughter by not reciprocating with a laugh. What is interesting here is the identity work that Nigel is doing. As Jayyusi (1984: 39) points out, for each incumbent of an identity involved in a particular activity there is an expectable standard of performance, and failure to display such a standard may result in a deviant identity being attributed. In this case, a predicate (i.e., expectable characteristic) of team member is participating in the talk. By laughing at Liz's word search, Nigel is treating Liz as having a deviant identity because her contribution (i.e., the suggestion to subscribe to Time) is treated as not meeting the required standard of performance. Nigel's irony and the identity work it entails therefore 'does' exclusion (see Day 1998: 169).

In terms of facilitation and popular management prescriptions of facilitative language use, one could give the advice to avoid irony and avoid affiliating with irony if only by reciprocating a smile because it does identity work that excludes people from participating in the meeting. Significantly, it also illustrates the importance of examining utterances in their sequential environment:

3 Horse and Hounds is an English magazine concerned with hunting. Town and Country and Home and Garden appear to be fictitious magazine titles that would be inappropriate to use for the teaching of English. 
initiating a word search is not in itself facilitative (as shown in the previous extract) because the action that an utterance performs is negotiated in talk and, as shown above, an invitation to participate in word search can be subverted through the use of irony. Significantly, as this analysis reveals, laughter is essential in doing disempowerment yet none of the texts in the corpus discuss laughter as if its interactional importance escapes the attention of popular management writers.

\subsection{What do you think?}

In the next extract, this paper focuses on a fine-grained analysis of the action that the so-called facilitative expression "what do you think" does. This is significant since all 10 articles in the corpus that prescribe facilitative language include this expression, or slight variations thereof, because it is an open question which (it is claimed) will lead to more participation because it invites people to reply freely and openly. However, as will be demonstrated, whilst it does mediate turns, subsequent talk reveals that there is nothing necessarily facilitative in this and that, in fact, in this case "what do you think" does disempowerment. By mediating turns strategically, the participation framework is changed so that a consensus that aligns with Alice is built. On the back of this consensus, a decision is then announced not to subscribe to Time and significantly space is allowed so that Liz has an opportunity to change her displayed opinion and so also align with the emerging team consensus.

\begin{tabular}{|c|c|c|}
\hline 29 & $\mathrm{~L}$ & $\begin{array}{l}\text { [moi je suis d'avis] qu'on qu'on s'abonne }((\text { gaze to } \mathrm{A})) \\
\text { [me my opinion is] that we that we subscribe }\end{array}$ \\
\hline 30 & A & $\begin{array}{l}\text { qu'est-ce que vous en pensez }[(.3((\text { moves gaze from } L \text { to } B)))] \\
\text { what do you think }\end{array}$ \\
\hline 31 & & [((gaze to A, nod, turns gaze to $L))]$ \\
\hline 32 & $\mathrm{~L}$ & .hhh $([$ \\
\hline 33 & A & $\begin{array}{l}\text { [le problème] c'est que ça va rester où ça [va être ] lu par qui >pour }<\text { prendre chez } \\
\text { [the problem] is that that will stay where it [ will be ] read by whom }>\text { to }<\text { take }\end{array}$ \\
\hline 34 & $\mathrm{~L}$ & $\begin{aligned} & {[\uparrow \text { oh ça }] } \\
& {[\uparrow \text { oh that }] }\end{aligned}$ \\
\hline 35 & A & $\begin{array}{l}\text { lui et le lire encore un truc qui va disparaître }(.2) \quad \text { [c'est ] ça enfin je ne sais pas } \\
\text { home and read another thing that will disappear (0.2) [it's ] that well I don't know }\end{array}$ \\
\hline 36 & B & $(($ nod, gaze to $\mathrm{A}))$ \\
\hline 37 & $\mathrm{~L}$ & $(($ nod $))[$ uhu $]$ \\
\hline 38 & A & $\begin{array}{l}\text { qu'est-ce que vous en pensez ((gaze to B and } \mathrm{N})) \\
\text { what do you think }\end{array}$ \\
\hline
\end{tabular}

At the end of this word search, Liz then makes an assessment (line 29) "me my opinion is that we subscribe". Since this utterance projects future action, it could be interpreted as making an assessment that could be hearable as a decision (Huisman 2001) and thus it would significantly empower Liz as the decision-maker in the group. However, the 'meaning' of an utterance is dialogic and is negotiated in talk: for this utterance to be oriented to as a decision it would need the others in the group to orient to it as such and confirm it in a next turn. In this case, no confirmation or disconfirmation, which is sequentially implicit, is forthcoming. Instead, Alice self-selects (line 30: what do you think) and she shifts gaze to Beth. This changes the participation framework and mediates turns so that Beth is selected to give a second assessment. Beth meets Alice's gaze but instead of taking the floor, she acknowledges that the turn is addressed to her with a nod and gazes at Liz thus passing the floor to her. Liz takes an inbreath and starts her turn but she is overlapped by Alice (line 32) who takes the floor and provides an assessment and denies voice to Liz. Alice now provides an assessment which is conditionally relevant to Liz's first assessment. This assessment again frames the proposal to use a magazine as a problem (line 33: the problem is that 
that will stay where it [will be ] read by whom $>$ to $<$ take home and read another thing that will disappear (0.2) [ it's ] that well I don't know).

In short, the utterance 'what do you think' does not necessarily do facilitation. In this case, it is used to mediate turns in such a way as to continue the exclusion of Liz and when Liz does seek to make an assessment, the assessment slot is filled by Alice, who responds to her own question. Moreover, Liz orients to this assessment as repair. In line 34, Liz produces what Heritage (1984) has described as a change of state token ( $\uparrow$ oh that), whereby Liz hearably displays that she has undergone a change in her state of knowledge. Following Heritage (1984: 315), "oh" is regularly used to acknowledge receipt of other initiated repair. Thus, in this case, Liz orients to Alice's assessment as a repair of her suggestion that we subscribe and she acknowledges the repair and displays that she has changed her state of knowledge in response to this repair. Liz is thus beginning to reverse her displayed opinion in the face of counter arguments. Moreover, line 37, at what could be the end of Alice's turn, Liz nods and backchannels uhu. This constitutes a non-verbal display of agreement with the emerging talk and so, in this case, Liz displays a claim to be "active participant in the delivery of the activity" (Heath 1992: 109). In short, Liz is beginning to adjust her displayed opinion to align with Alice. Thus, because Liz begins to change her opinion in the face of an emerging consensus to the contrary, the utterance "what do you think" has been used to do power and exclusion rather than empowerment. Consequently, this analysis stands in stark contrast to the texts on facilitation that claim that open questions invite "participation and idea sharing" (McManus 2006: 24).

\subsection{Collaboratively constructed three-part list}

The talk continues on the theme of subscribing or not to Time for the next 28 lines (see appendix three for a full transcript) which have been omitted for reasons of space. In the next extract, Liz becomes an active participant in the authoring of a team formulation not to subscribe to Time. This is achieved through the co-authoring of single turn at talk which, as Sacks (1992 vol. 1: 145) points out, is one way of doing being a team.

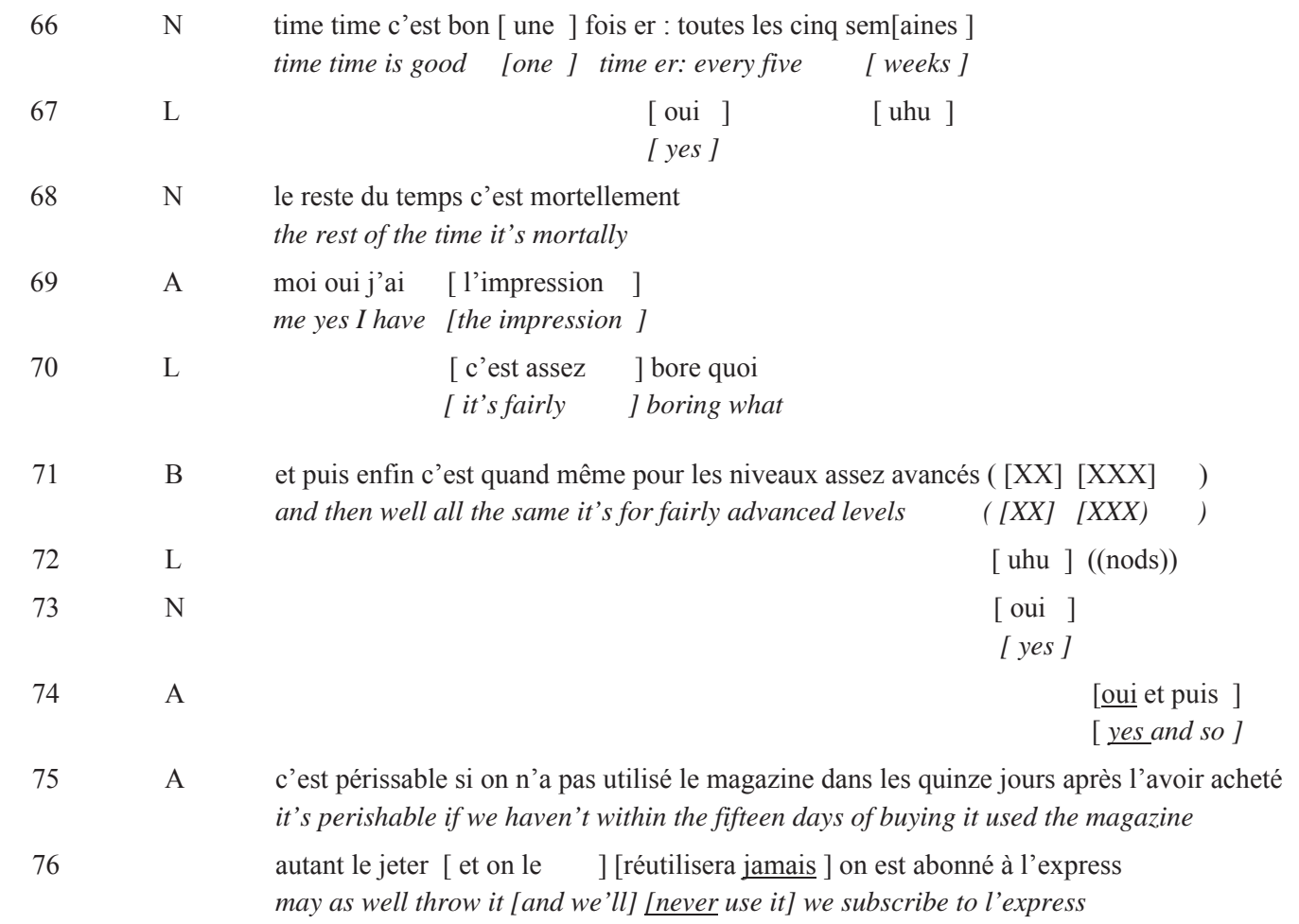


When Nigel arrives at what is retrospectively the end of his turn (line 68), Alice self-selects to begin a turn. She does this before Nigel can complete his assessment of Time. However, Liz overlaps Alice's turn and self-selects to complete Nigel's assessment [it's fairly] boring what. This aligns with Nigel's projection of a negative assessment through the modifier 'mortellement'. Thus, Liz has now moved from supporting the idea of subscribing to Time to a completely opposite opinion that Time is 'fairly boring'. Furthermore, retrospectively, Liz's 'fairly boring', turns out to be the first part of a co-authored three-part list. Beth then self-selects (line 71) to take the floor. She begins her turn 'and' which is hearable as a collaborative continuer (Vorreiter 2003: 2). In other words, it is the sequential continuation of a (possibly) syntactically complete turn by another speaker which adds further material to the host turn and, by adding another reason not to subscribe to Time, it becomes a second part of a three-part list (it's for fairly advanced levels). Beth's collaborative continuer is accepted by Liz's ' $u h u$ ' plus nod (line 72) and Nigel's 'yes' (line 73). Alice (line 74) self-selects to overlap Beth's continuing turn and, by speaking more loudly (yes and so), she claims the floor. Alice's utterance begins with 'and' which is a collaborative continuer which is 'parasitic' on the turn-in-progress and continues the turn syntactically and pragmatically. In this case, Alice uses her turn to provide a third part to the emergent list (it's perishable). Thus, a co-constructed version of the situation is beginning to emerge and significantly, Liz, through the use of backchannels of agreement, is an active participant in this process. She therefore completes the reversal of her original displayed opinion in favour of subscribing to Time and now comes into alignment with Alice's opinion not to subscribe to Time.

\subsection{Announcing the decision not to subscribe}

Finally, once Alice has used her discursive right to mediate turns to alter the participation framework and recycle an issue until a group consensus which concurs with her version of the organisation emerges, she can then announce a decision. In the following extract, Alice builds on this team talk to formulate a future state of affairs which is ratified both as it emerges and retrospectively. Consequently, the formulation becomes a decision. Significantly, this decision goes against the proposal which Liz has made earlier in the talk. Thus, by changing the participation framework and opening up the discussion, Alice is able to 'enlist' the support of Nigel and Beth to her ideas. Liz 'goes with the flow' and over several turns she reverses her position and then finally, based on this consensus, she comes to a point where she actively agrees with a view that is diametrically opposed to the opinion she ventured at the beginning of the interaction. Thus, the so-called facilitative expression what do you think, whilst it is used to mediate turns, does not necessarily equate with facilitation since mediating turns can be done so as to extend decision-making talk until a joint commitment to future action which aligns with the manager's view emerges and then a decision (again which aligns with the management line) can be announced. 


\begin{tabular}{|c|c|c|}
\hline 77 & $\mathrm{~N}$ & $\begin{array}{l}\text { [ oui c'est ça ] } \\
\text { [yes that's it] }\end{array}$ \\
\hline 78 & $\mathrm{~L}$ & [ uhu uhu uhu ] \\
\hline 79 & A & $\begin{array}{l}\text { ils nous demandent l'abonnement on arrête [car ] c'est la même chose [ erm ] } \\
\text { they ask us for the subscription we stop [because] it's the same thing [erm] }\end{array}$ \\
\hline 80 & $\mathrm{~L}$ & {$[\mathrm{uhu}]$} \\
\hline 81 & A & $\begin{array}{l}\text { maintenant on achètera les magazines ou les revues quand on a des stages très précis } \\
\text { now we will buy the magazines or journals when we have courses very precise }\end{array}$ \\
\hline 82 & & $\begin{array}{l}\text { [ pour ] lesquels on a besoin [pour] ]esquels on souhaite que ça devienne la ressource } \\
\text { [ for ] whom we have a need[ for ] whom we want that it becomes a resource }\end{array}$ \\
\hline 83 & $\mathrm{~L}$ & [ uhu ] ((nod)) \\
\hline 84 & $\mathrm{~N}$ & [oui ] ((looks up, gazes at Alice, smiles )) \\
\hline & & [yes ] \\
\hline 85 & $\mathrm{~B}$ & {$[(($ nod $))]$} \\
\hline 86 & A & $\begin{array}{l}\text { pédagogique SMET ça a marché super bien je pense qu'on va aller plus là-dessus parce que } \\
\text { pedagogic SMET that works very well so I think that we'll go more in that direction because }\end{array}$ \\
\hline 87 & & $\begin{array}{l}\text { l'abonnement aujourd'hui n'a pas beaucoup de sens } \\
\text { the subscription today doesn't make a lot of sense }\end{array}$ \\
\hline 88 & $\mathrm{~L}$ & [ uhu uhu ] \\
\hline 89 & $\mathrm{~N}$ & $\left.\begin{array}{ll}{\left[\begin{array}{ll}\text { oui } & \end{array}\right]} \\
{[\text { yes }}\end{array}\right]$ \\
\hline 90 & $\mathrm{~B}$ & $\begin{array}{l}\text { par contre en espagnol on a un problème il y a pas beaucoup de stagiaires } \\
\text { on the other hand in spanish we have a problem because }\end{array}$ \\
\hline
\end{tabular}

In line 81 (now we will buy the magazines or journals when we have a course very precise), Alice projects future action which is hearable as the first part of a decision-confirmation/disconfirmation pair (Heritage and Watson 1979: 141). As she takes her turn, the other participants backchannel agreement: Liz and Beth nod, and Nigel backchannels 'yes', looks up at Alice, smiles and moves his hands palm down, slightly raised across each other indicating understanding, agreement and the lack of need to pursue the topic further. Thus, the decision is ratified as it emerges. Alice, however, continues her 'decision-turn' and justifies her decision by citing the example of SMET (a client of the company) which 'worked well'. She then reiterates the decision (so I think that we'll go more in that direction) and adds further justification (the subscription today doesn't make a lot of sense). At the end of this turn, Liz backchannels ' $u$ hu' plus a nod and Nigel gives an agreement token 'yes'. A decision - an explicit formulation of future affairs and a projection of future action - is thus announced by Alice and it is confirmed both as it is in progress and retrospectively at the end of Alice's turn. Once the decision has been made, the topic of magazines is hearable as closed and Beth self-selects (line 90) to carry out a stepwise topic transition to the use of magazines for the Spanish classes.

\subsection{Summary of analyses}

Despite Alice's professed facilitative inclinations, the above analysis reveals that she tends to do disempowerment rather than empowerment. Even though the topic is elicited by an open question, which popular management texts prescribe as a facilitative action because it allows participation, in fact, when viewed as part of a larger sequence, it does no more than elicit topic which Alice immediately assesses negatively and so, by judging the idea immediately, marginalizes Liz's contribution. First, Alice does this by, making an assessment in a sequentially first position. Second, Liz's contribution is marginalized because Nigel treats Liz's assessment ironically by not 
providing a conditionally relevant response to a word search and Alice, by laughing at Liz's contribution, also seeks to exclude her from the talk. Finally, by inviting participation with the utterance "what do you think", Alice changes the participation framework and allows a space in which Liz reverses her displayed opinion and aligns with Alice's point of view. Once consensus has been reached, Alice can announce her assessment not to subscribe to Time as the group's decisions - a decision with which Liz now fully aligns.

\section{Observations}

Popular management literature sets itself up as being in a position to prescribe which expressions to use in order to 'do' a particular management style. This has given rise to lists of expressions that are assumed to produce the management styles in question and which, therefore, implicitly suggest a one-to-one correspondence between language and the action or actions that these utterances perform. Such lists of expressions are sometimes then complemented with examples of constructed dialogues which exemplify the point the management writers are attempting to make. Yet, due to the imagined nature of this literature, popular management writers may be sustaining myths of what management talk should be rather than descriptions of what management talk actually is (see Schwartzman 1989). The potential failing of such literature is that it ignores the indexical and sequential nature of language and, whilst the writers' intuition may certainly be right in some circumstances, the context-bound nature of the meaning of language means that such management writers' claims may be gross over-simplifications. The consequence of this is that popular management writers may, in fact, be leading managers up the linguistic garden path. Cameron (2000), for example, argues that the prescriptive language 'skills' imposed on supermarket employees fail because they are contextually inappropriate and this leads to the promotion of language behavior that is problematic in the context of a supermarket.

First, this paper has shown that two expressions, anything else and what do you think, do not do facilitation as predicted in management texts. According to such texts, open questions such as these are supposed to allow the group to respond freely. As Cameron (2000: 71) notes, because of the assumption that form and function are intimately locked together, "the open/close question distinction is fetishised in virtually every set of materials that I have come across, and implies a very simple and literal model of how communication works". This observation is borne out in the invented dialogue discussed in section two in which the facilitative effect that such open questions are supposed to have is given (McManus 2006: 23). Yet, the open question anything else which appeared in the corpus of facilitative expression is, in the extract analyzed, used as a turn initial topic elicitor which invites the next topic of talk. However, when more intra-textual data is taken into consideration, the provision of a slot for other initiated topic selection is not necessarily facilitative since the chair immediately classes the implicit suggestion in the topic (i.e., of subscribing to Time) as a problem without allowing the hierarchical subordinate to express her ideas as one would expect a seemingly facilitative expression to engender. This observation, contrasts with the function of anything else in glossaries of facilitative expressions where it is assumed, by virtue of the fact that it is an open question, to garner participation. Similarly, the expression what do you think which popular management writers also cite as a facilitative expression does not necessarily 'do' facilitation simply because it is an open question. In this case, what do you think changes the participation structure so as to bring Nigel and Beth into the talk to build a consensus that is in the manager's favor. Eye gaze accompanying the talk often signals Beth and Nigel as recipients of turn transition and so the exclusion of Liz is continued. Moreover, by changing the participation framework, Alice allows for a consensus to be built up which goes against Liz's idea of subscribing to Time. In this case, what do you think acts to recycle talk until consensus which goes in the management's favor is achieved and on the back of such consensus a decision can be made. Thus, rather than allowing Liz to develop her ideas, the expression what do you think allows space for Liz to come on side and join the group consensus without loss of face. The actual 
use of what do you think here, contrasts starkly with prescriptions that it does facilitation by inviting participation simply because it is an open question.

Second, the CA analysis reveals ways of doing facilitation that are not to be found in the corpus. This can be seen in the case of help in a word search which does facilitation by valuing Liz's contribution to the talk and seeking to extend her involvement in the talk. It can also be seen in the way in which some turns are collaboratively constructed. CA also reveals the machinery of talk, unmentioned in the prescriptive texts, which do not do facilitation but yet knowledge of such machinery could be interesting for practitioners if they are to avoid linguistic pitfalls that may disempower other participants. For example, sequentially going first when giving assessments is hearable as claiming epistemic primacy and thus the speaker, rather than allowing the other to give their view, closes down the discussion and so does not do facilitation. The fine-grained analysis also reveals how irony and laughter can do exclusion and so disempower. Yet, none of the texts in the corpus of facilitation discuss laughter as a communicative act nor do they make practitioners aware of how irony works on a turn-by-turn basis. Taken together, these observations add credence to Sacks' (1984) claims that by not using data-driven approaches, one only comes up with the imaginable. In fact, prescriptive non-data-driven 'how-to' books and websites do not discuss certain aspects of facilitation (or workplace interaction more generally) because some of the machinery of talk flies under the radar, as it were, of what counts as management communication in the popular imagination. A summary of these findings in tabular form can be seen in appendix four.

\section{Conclusions}

Whilst this study relies on a single case analysis, and in other contexts the so-called facilitative expressions (what do you think and anything else) that are highlighted in this paper may well 'do' facilitation, this paper points to the dangers of relying on intuitive understandings of what happens in meetings to provide catch-all prescriptions of how to 'do' facilitation. Indeed, this paper has demonstrated that the supposedly facilitative expressions (what do you think and anything else) do no more than mediate turns. To imply that such expressions have a one-to-one relationship with facilitator identity is ideologically rather than data-driven. The danger of over-relying on such intuition is that myths of what happens in meetings could be promoted and, in this way, managers taking such literature too seriously could well be led up the garden path concerning the actions that their talk performs. In short, this paper agrees with Cameron's (2000: 178/9) conclusions that a prescriptive approach to communication training:

\footnotetext{
“does not produce 'better communication', nor does it produce more 'skilled' and 'empowered' communicators. It cannot produce those things, because it negates the single most important ability of a truly skilled communicator, the ability to assess what is going on in a situation and choose strategies that are likely to be effective in that situation".
}

This paper, therefore, joins calls for more management literature to be based on the actual observation of naturally-occurring interaction (see, for example, Boden 1994, Samra-Fredericks and Bargiela-Chiappini 2008, Schwartzman 1989). If popular management writers heed this call, then they may be in a position to provide their readership with not only a better understanding of what is going on in workplace interaction but also with a better description of how these actions are achieved. The fine-grained analysis of the interaction presented in this paper could therefore add insights to management 'how-to' texts on facilitation in two ways. First, it could be used to make visible the (seen but unnoticed) machinery of talk that does facilitation (e.g. helping with word searches). Second, it could help to dispel myths that certain expressions are in themselves enough to talk into being certain management styles. However, in order to avoid such contexualized descriptions becoming reified into decontextualized prescription, it is important to promote a linguistic awareness in practitioners so that they are sensitive to context. This could be achieved through combining observation-based methods of analysis of naturally-occurring talk with re- 
flective practice. Reflective practice can be defined as reflecting on intuitive understandings of experienced phenomena, such as talk at work, in order to make it amenable to critical scrutiny, and, ultimately, improvement (Schön 1983). Housley and Fitzgerald (2000) outline how conversation analysis could be a useful tool in the development of reflective practice and practitioner based research. They (Housley/Fitzgerald 2000: 15) argue that "the analysis of members' communicative and interactive activities within meetings (and potentially other contexts) could provide a way through which practitioners could reflect upon and analyze aspects of their practice." This synergy between CA and reflective practice is created because transcription is used as an estrangement device so that the seen but unnoticed machinery of talk in (workplace) interaction becomes available for analysis and reflection. Whilst linking reflective practice to CA inspired research is relatively rare, Roberts and Sarangi (2003) and Jones and Stubbe (2004), for example, have already documented their attempts to make practitioners more aware of their talk through the study of recordings of their own workplace interaction. They propose an action research approach based on reflective practice whereby participants study their own workplace interaction and devise strategies to improve it. In this way, practitioners are not treated as consumers of prescriptions that may appear remote from actual practice, rather they become critical observers of their own practice. Jones and Stubbe (2004) report successful implementation of such reflective practice as they say:

"we received a great deal of positive feedback from informants about the benefits to them, both personally and professionally, of their involvement in the data collection and feedback processes. For instance, people often reported that they had gained useful insights simply by monitoring their actual interaction patterns as compared to their perceptions or by listening to their own recordings,"

Finally, this paper leaves questions unanswered which might be the focus of further research. Firstly, more quantitative research could be carried out in order to ascertain the extent to which socalled facilitative expressions do (or do not do) facilitation. Further, if doubt has been cast on the accuracy of the linguistic prescriptions of popular management writers in the case of facilitation, further research could be carried out to investigate to what extent the doubts raised in this paper are valid for other areas of popular management writing such as, for example, decision-making, team building and so on. Finally, if popular management texts do not provide prescriptions of management-talk that are useful to the practitioner, the question of what such management texts actually achieve becomes extremely pertinent. 


\section{Appendix one: Glossary of facilitative language ${ }^{4}$}

\begin{tabular}{|c|c|}
\hline $\begin{array}{l}\text { Setting of ground rules } \\
\text { "Our purpose today..." } \\
\text { "What is the purpose of our } \\
\text { meeting?" } \\
\text { "What would be the ideal outcome?" } \\
\text { "Where do you want to have got to } \\
\text { when we go out that door?" } \\
\text { "Relax and enjoy the journey" } \\
\text { "Everyone's opinion is valued, there } \\
\text { are no wrong answers" } \\
\text { "All ideas are valued" } \\
\text { "It's an honour to work with you" }\end{array}$ & $\begin{array}{l}\text { Garnering participation } \\
\text { "I'm wondering how this might } \\
\text { look/appear/feel/seem to you?" } \\
\text { "I invite you to..." } \\
\text { "I'd like to invite you to participate } \\
\text { in..." } \\
\text { "Tell me about a time when..." } \\
\text { "I'm curious to know what others } \\
\text { think" } \\
\text { "What do others think?" } \\
\text { "Does anyone else have } \\
\text { [something]?" }\end{array}$ \\
\hline $\begin{array}{l}\text { Acknowledging participants' contributions } \\
\text { "That's an excellent thought. You } \\
\text { are very (sincere praise)." } \\
\text { "That interests me, say more" } \\
\text { "Thank you for sharing" } \\
\text { "Great- good- I like it- excellent- Spot } \\
\text { on" }\end{array}$ & $\begin{array}{l}\text { Reflecting and clarifying } \\
\text { "What I have heard is..." } \\
\text { "Am I correct in observing that..." } \\
\text { "So what you're saying is..." } \\
\text { "What I'm hearing is...Is that right?" } \\
\text { "Please clarify" } \\
\text { "What I hear you saying..." } \\
\text { "Can you help me be more clear in } \\
\text { my mind about..." }\end{array}$ \\
\hline $\begin{array}{l}\text { Probing } \\
\text { "Say more..." } \\
\text { "Can you say more about..." } \\
\text { "Could you say more?" } \\
\text { "Tell me more about that..." } \\
\text { "Can you tell me more about that?" } \\
\text { "Please, tell me more about that." } \\
\text { "Yes, please go on." } \\
\text { "Say more about that if you will..." } \\
\text { "Please tell me more about what you } \\
\text { mean when you stated..." } \\
\text { "Tell us a little more about this." }\end{array}$ & \\
\hline
\end{tabular}

4 Rixon et al. (2006). This glossary is based on response to a survey sent to self-declared facilitators, asking the question: "List some words or phrases you use to engage/connect with others in your facilitation practice". 


\title{
Appendix two: transcription symbols used
}

approximate length of pause in seconds

[but]

overlapping utterances

$\uparrow$

rising intonation

$\downarrow$

falling intonation

sound stretching

$£$

smile voice

$>$ problem $<$

spoken more quickly that surrounding words

$<$ problem >

( in ) spoken more slowly than surrounding words

( ) not clear. Transcriber's best guess

$(\mathrm{XX})$ untranscribable syllable in untranscribable talk

${ }^{\circ}$ saying ${ }^{\circ}$ description of an activity

.hh spoken more softly than surrounding talk inbreath

\section{Appendix three: full text}

\author{
1 A autre $\uparrow$ chose \\ anything $\uparrow$ else \\ 2 L une fois on avait une fois on avait évoqué erm ((gaze to A)) l'idée de prendre \\ once we had once we had the erm idea of taking \\ 3 L un magazine \\ a magazine \\ 4 B ah oui \\ ah yes \\ 5 A de s'abonner $=$ \\ of subscribing $=$ \\ 6 L =de s'abonner à time maga[zine ] \\ =to subscribe to time maga[zine] \\ $7 \quad \mathrm{~A}$ \\ [time] c'est américain [c'est] ça le problème on va \\ [time] is american [it's] that the problem that we'll \\ 8 L [uhu ] \\ 9 A s'abonner a un truc americain et après on va avoir la moitié des stagiaires vont \\ subscribe to an american thing and then we'll have half the students \\ 10 A dire il faut de l'anglais ((smiles gazes to B)) \\ saying english is needed \\ 11 B ((gaze to A, smiles then gaze to $\mathrm{N}))$ \\ 12 L mais: oui peut-être mai:s j'utilise tellement peu d'américain que ça serait bien d'avoir \\ but: yes maybe but: I use american so little that it would be good to have
}




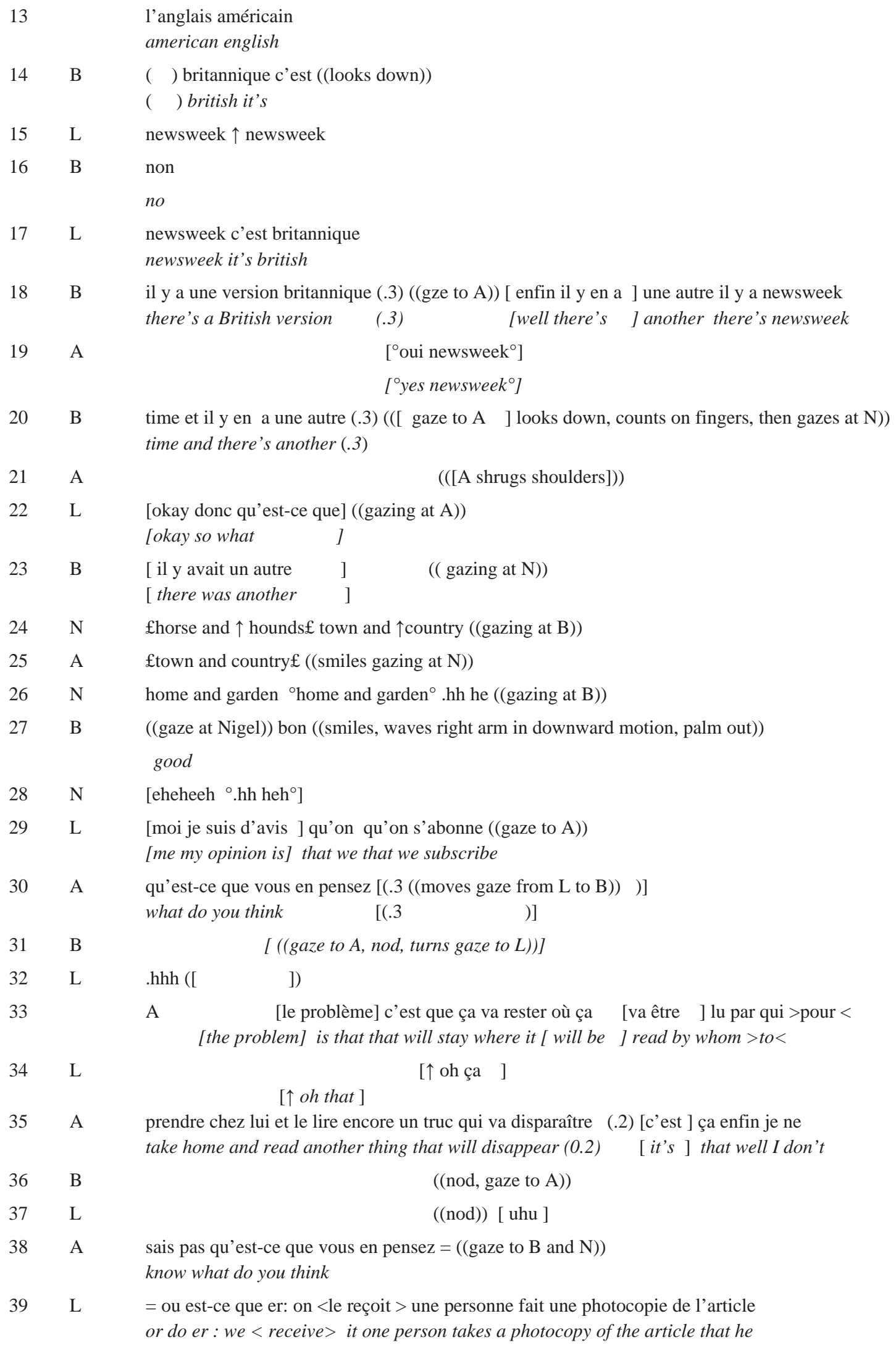


40 L qu'il préfère et il met ça dans un classeur qui reste ${ }^{5}$ [l'article] qu'il préfère prefers and that he puts in a folder which stays [ the article] which he prefers

41 B [.hhhh]

$42 \mathrm{~L} \quad$ et ça (.) je sais pas deux articles par semaine et après le magazine sera là and that (.) I don't know two articles per week and after the magazine will be there

(.) comme ça ((both arms extended palms up shifts gaze to $\mathrm{N})$ )

(.2) like that
$41 \quad$ B $\quad[. h h h h h$ ]
$42 \quad \mathrm{~N} \quad[(($ grins, averts gaze, gazes to $\mathrm{B})]$
43 L $\quad[$ ça marche $\uparrow$ pas $\downarrow$ non ] $\quad($ gazing at $\mathrm{N})$ )
[ that doesn't $\uparrow$ work $\downarrow$ no ]
44 B enfin dans un er: sens pédagogique éventuellement ça pourrait well in a er: pedagogic sense maybe that could

45 B être la même chose qu'on fait (dans) la gestion des huit heures be the same thing that we do (in) the management of the eight hours

46 B par semaine ${ }^{6}$ on peut sélectionner des sujets éventuellement mais je pense que by week we can possibly select the subjects but I think that

47 B c'est ( ) [je ne sais pas ]

it's ( ) [I don't know]

48 A [ $\quad$ le problème $<$ ] c'est que les sujets sont très er :

$[>$ the problem $<]$ is that the subjects are very er:

49 N éphémères

ephemeral

50 A [très ] [périssables] en fin de compte ${ }^{\circ}$ parce que un mois plus tard ${ }^{\circ}$

[very] [perishable] at the end of the day ${ }^{\circ}$ because one month later ${ }^{\circ}$

51 B [oui $][(\quad)]$

[yes ] [ ( )]

52 L [voilà] ((nods))

[there it is]

oui c'est pour ça que je pense qu'on a tous internet maintenant [ on ] peut yes it's for that that I think that we all have internet now [we ] can

s'abonner a l'economist [il y a ] (

[yes]

$57 \quad$ L
subscribe to the economist [ there is ] (

) c'est une ressource ) it's a resource

qui est formidable er: ça ne coûte rien du tout [ on ] a accès à beaucoup that is formidable er: that cost nothing at all [ we ] have access to a lot of

5 i.e., the photocopy of the article stays in the folder. In this way the teachers will have access to the photocopies but not to Time itself so that the magazine itself will not disappear.

6 Semi-intensive lessons which consist of eight hours teaching per week. 


\begin{tabular}{|c|c|c|}
\hline 60 & $\mathrm{~L}$ & [ uhu ] ((nods)) \\
\hline 61 & $\mathrm{~N}$ & $\begin{array}{l}\text { d'articles er: time [ vous] avez the times ou telegraph vous avez toutes les revues qui } \\
\text { articles er: time }[\text { you ] have the times or telegraph you have all the }\end{array}$ \\
\hline 62 & $\mathrm{~L}$ & [ uhu ] \\
\hline 63 & A & $\begin{array}{l}\text { nous intéressent (.) vous avez au moins l'article le plus intéressant de la } \\
\text { magazines that interest us (.) you have at least the most interesting article of the }\end{array}$ \\
\hline 64 & $\mathrm{~N}$ & $\begin{array}{l}\text { [ semaine ] qui est gratuit }[\text { et }] \text { puis on varie }[>\text { car si }<\text { ] on se contente } \\
{[\text { week ] which is free [ and ] also we vary }[>\text { because if }<] \text { we stay with }}\end{array}$ \\
\hline 65 & $\mathrm{~L}$ & {$[$ uhu $](($ nods $)) \quad[\quad$ uhu $\quad]$} \\
\hline 66 & $\mathrm{~N}$ & $\begin{array}{l}\text { time time c'est bon [ une ] fois er: toutes les cinq sem[aines ] } \\
\text { time time is good [one ] time er: every five [weeks ] }\end{array}$ \\
\hline 67 & $\mathrm{~L}$ & $\begin{array}{l}{[\text { oui }]} \\
\text { [yes ] }\end{array}$ \\
\hline 68 & $\mathrm{~N}$ & $\begin{array}{l}\text { le reste du temps c'est mortellement } \\
\text { the rest of the time it's mortally }\end{array}$ \\
\hline 69 & A & $\begin{array}{l}\text { moi oui j'ai [ l'impression ] } \\
\text { me yes I have [the impression ] }\end{array}$ \\
\hline 70 & $\mathrm{~L}$ & $\begin{array}{ll}{[\text { c'est assez }} & \text { ] bore quoi } \\
{[\text { it's fairly }} & \text { ] boring what }\end{array}$ \\
\hline 71 & $\mathrm{~B}$ & $\begin{array}{l}\text { et puis enfin c'est quand même pour les niveaux assez avancés }([\mathrm{XX}] \\
\text { and then well all the same it's for fairly advanced levels }\end{array}$ \\
\hline 72 & $\mathrm{~L}$ & [ uhu ] $(($ nods $))$ \\
\hline 73 & $\mathrm{~N}$ & $\begin{array}{l}{[\text { oui ] }} \\
\text { [yes ] }\end{array}$ \\
\hline 74 & A & $\begin{array}{l}{[\underline{\text { oui et puis }]}} \\
{[\text { yes and so ] }}\end{array}$ \\
\hline 75 & A & $\begin{array}{l}\text { c'est périssable si on n'a pas utilisé le magazine dans les quinze jours après l'avoir acheté } \\
\text { it's perishable if we haven't within the fifteen days of buying it used the magazine }\end{array}$ \\
\hline 76 & & $\begin{array}{l}\text { autant le jeter [ et on le ] [réutilisera jamais ] on est abonné à l'express } \\
\text { may as well throw it [and we'll] [never use it] we subscribe to l'express }\end{array}$ \\
\hline 77 & $\mathrm{~N}$ & $\begin{array}{l}\text { [ oui c'est ça ] } \\
\text { [yes that's it] }\end{array}$ \\
\hline 78 & $\mathrm{~L}$ & [ uhu uhu uhu ] \\
\hline 79 & A & $\begin{array}{l}\text { ils nous demandent l'abonnement on arrête [car ] c'est la même chose [ erm ] } \\
\text { they ask us for the subscription we stop [because] it's the same thing [erm] }\end{array}$ \\
\hline 80 & $\mathrm{~L}$ & {$[\mathrm{uhu}]$} \\
\hline 81 & A & $\begin{array}{l}\text { maintenant on achètera les magazines ou les revues quand on a des stages très précis } \\
\text { now we will buy the magazines or journals when we have courses very precise }\end{array}$ \\
\hline 82 & & $\begin{array}{l}\text { [ pour] lesquels on a besoin [pour]lesquels on souhaite que ça devienne la ressource } \\
\text { [ for ] whom we have a need[ for] whom we want that it becomes a resource }\end{array}$ \\
\hline 83 & $\mathrm{~L}$ & [ uhu ] $\quad(($ nod $))$ \\
\hline 84 & $\mathrm{~N}$ & $\begin{array}{l}\text { [oui ] ((looks up, gazes at Alice, smiles })) \\
{[\text { yes }]}\end{array}$ \\
\hline 85 & B & {$[((\operatorname{nod}))]$} \\
\hline
\end{tabular}




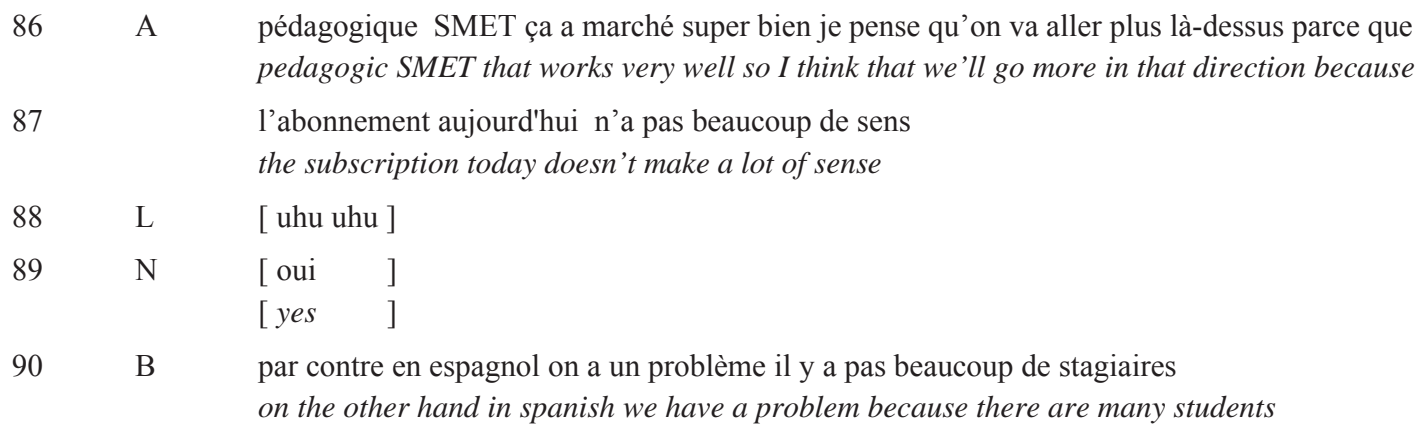

\section{Appendix four: Summary of the findings}

\begin{tabular}{|c|c|c|c|c|}
\hline & \multicolumn{2}{|c|}{ 'How-to' literature } & \multicolumn{2}{|c|}{ Fine-grained analysis } \\
\hline $\begin{array}{l}\text { Machinery of } \\
\text { talk/expression }\end{array}$ & Mentioned & Prescribed action & $\begin{array}{l}\text { Located in } \\
\text { analysis }\end{array}$ & in situ action performed \\
\hline Anything else? & yes & $\begin{array}{l}\text { By virtue of being open } \\
\text { questions, these }\end{array}$ & yes & $\begin{array}{l}\text { Topic initial elicitor }- \text { not } \\
\text { necessarily facilitative }\end{array}$ \\
\hline $\begin{array}{l}\text { What do you } \\
\text { think? }\end{array}$ & yes & $\begin{array}{l}\text { expressions are said to } \\
\text { lead to facilitative } \\
\text { interaction by inviting } \\
\text { participation. }\end{array}$ & yes & $\begin{array}{l}\text { Changed the participation } \\
\text { structure and allowed } \\
\text { space for consensus } \\
\text { which concurs with the } \\
\text { emerging management } \\
\text { opinion - not facilitative }\end{array}$ \\
\hline $\begin{array}{l}\text { Help with } \\
\text { word search }\end{array}$ & no & & yes & facilitative \\
\hline $\begin{array}{l}\text { Collaborative } \\
\text { completion }\end{array}$ & no & & yes & facilitative \\
\hline Laughter & no & & yes & Non-facilitative \\
\hline $\begin{array}{l}\text { First } \\
\text { positioned } \\
\text { assessments }\end{array}$ & no & & yes & Non-facilitative \\
\hline Irony & no & & yes & Non-facilitative \\
\hline
\end{tabular}

\section{References}

Boden, Deidre 1994: The business of talk: organizations in action. Cambridge: Polity Press.

Buttny, Richard 2001: Therapeutic humor in retelling the clients' tellings. In Text 21 (3), 303-327.

Button, Graham/Casey, Neil. 1984: Generating the topic: the use of topic initial elicitors. In Atkinson J. Maxwell/Heritage, John (eds.), Structures of Social Action: Studies in Conversation Analysis. Cambridge: Cambridge University Press, 167-190.

Cameron, Deborah 2000: Good to Talk. Living and Working in a Communication Culture. London: Sage

Clift, Rebecca 1999: Irony in conversation. In Language in Society, 28, 523-53.

Clifton, Jonathan 2006: A conversation analytical approach to business communication: the case of leadership. In Journal of Business Communication 43(3), 202-219.

Day, Dennis 1998: Being ascribed and resisting membership in an ethnic group. In Antaki, Charles/Widdicombe, Sue (eds.), Identities in Talk. London: Sage, 151-170.

Have, Paul ten 1999: Doing conversation analysis: a practical guide. London: Sage. 
Heath, Christian 1992: Gesture's discreet tasks: Multiple relevancies in visual context and in the contextualization of language. In Auer, Peter/di Luzio, Aldo (eds.), The contextualization of language Amsterdam: Benjamins, 101128.

Heritage, John 1984: A change-of-state token and aspects of its sequential placement. In Atkinson, J. Maxwell/Heritage, John (eds.), Structures of Social Action: Studies in Conversation Analysis. Cambridge: Cambridge University Press, 299-345.

Heritage, John/Raymond, Geoffrey 2005: The Terms of Agreement: Indexing Epistemic Authority and Subordination in Talk-in-Interaction. In Social Psychology Quarterly 68, 15-38.

Heritage, John/Watson, Rod 1979: Formulations as conversational objects. In Psathas, George (ed.), Everyday language: studies in ethnomethodology. New York: Irvington, 123-162.

Housley, William/Fitzgerald, Richard 2000: Conversation analysis, practitioner based research, reflexivity and reflected practice. In Ethnographic studies 5, 27-41.

Huisman, Marjan 2001: Decision-making in meetings as talk-in-interaction. International Studies of Management \& Organization 31 (3), 69-90.

Hutchby, Ian/Wooffitt, Robin 2008: Conversation analysis: Principles, practices and applications (2nd edition). Cambridge: Polity Press.

Jayyusi, Lena 1984: Categorization and the moral order. Boston, etc.: Routledge \& Kegan Paul.

Jefferson, Gail 1979: A technique for inviting laughter and its subsequent acceptance declination. In Pasathas, George (ed.), Everyday language. Studies in ethnomethodology. New York: Irvington, 79-95.

Jones, Deborah/Stubbe, Maria 2004: Communication and the reflective practitioner: a shared perspective from sociolinguistics and organizational communication. In The International Journal of Applied Linguistics 14 (2), 185-211.

Labov, William 1972: Sociolinguistic patterns. Philadelphia, Pennsylvania: University of Pennsylvania Press.

McManus, Patty 2006: Coaching People. Boston, Massachusetts: Harvard Business School Publishing.

Moerman, Michael 1988: Talking culture: ethnography and conversational analysis. Philadelphia: University of Pennsylvania Press.

Nelson, Mike 2000: A corpus-based study of business English and business English teaching materials. Unpublished $\mathrm{PhD}$. Thesis. Manchester: University of Manchester. Available at [online] http://users.utu.fi/micnel/thesis.html (accessed on 19 March 2009).

Pomerantz, Anita 1984: Agreeing and disagreeing with assessments: some features of preferred/dispreferred turn shapes. In Atkinson, J. Maxwell/Heritage, John (eds.), Structures of Social Action: Studies in Conversation Analysis. Cambridge: Cambridge University Press, 57-111.

Pomerantz, Anita 2005: Using participants' video-stimulated comments to complement analyses of interactional practices. In te Molder, Hedwige/Potter, Jonathan (eds.), Conversation and Cognition. Cambridge: Cambridge University Press, 93-113.

Pomerantz, Anita/Fehr, B.J./Ende, Jack 1997: When supervising physicians see patients - strategies used in difficult situations. In Human Communication Research 23, 589-615.

Raymond, Geoffrey/Heritage, John 2006: The epistemics of social relationships: owning grandchildren. In Language in Society 35(5), 677-705.

Roberts, Celia/Sarangi, Srikant 2003: Uptake of Discourse Research in Interprofessional Settings: Reporting from Medical Consultancy. In Applied Linguistics 24(3), 338-359.

Rixon, Andrew/Waters, Viv/Rixon, Sascha 2006: Exploring the language of facilitation. In Group Facilitation: A Research and Applications Journal 7, 21-30.

Samra-Fredericks, Dalvir/Bargiela-Chiappini, Francesca 2008: Introduction to the symposium on the foundations of organizing: the contribution from Garfinkel, Goffman and Sacks. In Organization Studies 29 (5), 653-675.

Sacks, Harvey 1984: Notes on methodology. In Atkinson, J. Maxwell/Heritage, John (eds.), Structures of Social Action: Studies in Conversation Analysis. Cambridge: Cambridge University Press, 2-27.

Sacks, Harvey/Schegloff, Emmanuel/Jefferson, Gail 1974: A simplest systematics for the organization of turn taking for conversation. In Language 50, 696-735.

Schegloff, Emmanuel 1997: Whose text? Whose context? In Discourse and Society 8, 165-187.

Schön, Donald 1983: The reflective practitioner: how professionals think in action. New York: Basic Books.

Schwartzman, Helen 1989: The Meeting. New York: Plenum Press.

Tapsall, Linda 2000: Using applied conversation analysis to teach novice dietitians history taking skills. In Human Studies 23, 281-307. 
Vorreiter, Susanne 2003: Turn continuations: towards a cross-linguistic classification. In Interaction and linguistic structures 39. Available at [online] http://www.uni-potsdam.de/u/inlist/issues/39/Inlist39.pdf (accessed on 8 June 2008).

Williams, Marion 1988: Language taught for meetings and language used in meetings: Is there anything in common? In Applied Linguistics 9(1), 45-58.

Wong, Jean 2002: “Applying" conversation analysis in applied linguistics: Evaluating dialogue in English as a second language textbooks. In International Review of Applied Linguistics 40, 37-60. 
